Stanley, J. L., Sargeant, K. \& Smith, H. (1960). J. gen. Microbiol. 22, 206-218

\title{
Purification of Factors I and II of the Anthrax Toxin Produced in vivo
}

\author{
By J. L. STANLEY, K. SARGEANT \& H. SMITH \\ The Microbiological Research Establishment, Porton, near Salisbury, Wiltshire
}

SUMMARY: Highly labile factors (I and II) of anthrax toxin were purified from the toxic plasma of guinea-pigs just dead from anthrax by fractionation methods which involved the minimum of inactivation. The final preparations of factors $I$ and II, which still contained constituents of guinea-pig plasma, were toxic when injected together but innocuous when injected separately.

The specific, lethal and oedema-producing toxin of Bacillus anthracis found in the plasma of guinea-pigs dying of anthrax (Smith, Keppie \& Stanley, 1955) has two components which form a synergic mixture (Smith et al. 1956). One component (factor I) was deposited quickly by ultracentrifugation leaving the second component (factor II) in the supernatant fluid (Smith et al. 1956). Further purification of these factors was hampered by their extreme lability. The present paper describes fractionations whereby they were considerably purified without appreciable loss of toxicity. A brief report of some of this work has appeared elsewhere (Stanley \& Smith, 1958; Sargeant \& Smith, 1958).

\section{METHODS}

Anthrax toxin produced in infected guinea-pigs was obtained as described by Smith et al. (1955). It was imperative that the plasma of guinea-pigs should be collected within a few minutes of death from anthrax. When delay occurred here, or in the subsequent removal of bacteria, the tendency for factor I to lose activity and to aggregate and become insoluble during subsequent fractionation was more pronounced.

Diethylaminoethyl cellulose. This was described by Peterson \& Sober (1956). It was made in the laboratory from I.C.I. solka floc S.W. 40.B or bought from Eastman Kodak Co.

Assay of factors $I$ and II of anthrax toxin. Serial descending dilutions $(0.1 \mathrm{ml}$.) of the test sample (factor I or factor II) were injected intradermally into the shaven side of a rabbit, immediately after mixing each dilution with a fixed amount $(0 \cdot 1 \mathrm{ml}$.) of the complementary factor (either crude factor II or crude factor I; for preparation see below) at a concentration which just failed to produce a skin lesion when $\mathbf{0 . 2} \mathrm{ml}$. was injected alone. The oedematous lesions formed by these mixtures of factors I and II were observed $16 \mathrm{hr}$. after injection and the null point, i.e. the first dilution of the test sample not giving a positive reaction, was noted as a measure of factor I or factor II. The assay would detect twofold differences in activity. Rabbits replaced the guinea-pigs formerly used in this work (Smith et al. 1955; Smith et al. 1956) 
because the lesions on the rabbit could be observed more easily, and more samples could be assayed on one animal; this enabled all the samples from one fractionation to be compared on the same animal.

Assay for immunizing activity was as described by Smith \& Gallop (1956).

Preparative ultracentrifugation was carried out in the preparative angle rotor of the Spinco ultracentrifuge Model $\mathrm{L}$ at $100,000 \mathrm{~g}$ and at $0^{\circ}-5^{\circ}$. In the following text only the duration of ultracentrifugation is quoted.

Analytical ultracentrifugation was carried out in the analytical Spinco ultracentrifuge Model $\mathrm{E}$ at $250,000 \mathrm{~g}$. We are indebted to our colleagues K. Cammack and K. Grinstead for these observations.

Total carbohydrate was measured by the orcinol method of Sørensen \& Haugaard (1933).

Absorption of ultraviolet radiation was observed with a Unicam spectrophotometer.

Serological precipitation in gels. The methods and the anthrax antisera used are described in a subsequent paper (Sargeant, Stanley \& Smith, 1960).

Rabbit antiserum against normal heparinized guinea-pig plasma. Guineapig plasma (9 vol.) was mixed with a suspension of aluminium phosphate (1 vol.: $10 \mathrm{mg} . / \mathrm{ml}$.) and injected into rabbits intramuscularly ( $1.0 \mathrm{ml}$.) or intravenously $(0.5 \mathrm{ml}$.) twice with a 4-day interval. After 3 weeks the rabbits received intramuscularly 2 doses each of $0.5,1.0,2.0$ and $4.0 \mathrm{ml}$. of plasma on the Mondays and Fridays of 4 successive weeks. The serum was obtained 5 days after the last injection.

\section{RESULTS}

\section{The stability of factor $I$ in crude preparations}

The sources of factor I were crude washed deposit and the deposit purified (but partially inactivated) by washing five more times in the ultracentrifuge (see Smith et al. 1956).

The effect of $p H$ value at $0^{\circ}$. Samples of washed deposit (factor I null point $1 / 1024)$ at $\mathrm{pH} 7 \cdot 2$ were diluted with 7 parts phosphate buffer $(0.2 \mu ; \mu$ signifies ionic strength) $\mathrm{pH}$ values of $6 \cdot 2,6 \cdot 8,7 \cdot 1,7 \cdot 4,7 \cdot 7,8 \cdot 0,8 \cdot 3,8 \cdot 6$. After standing at $0^{\circ}$ for 5 days, the factor I null points of these samples (reciprocals) were: 256, 512, 512, 1024, 1024, 256, 256, 128, respectively. After washing the deposit five more times on the ultracentrifuge (Smith et al. 1956) its factor I activity rapidly decreased on standing at $0^{\circ}$, even at $\mathrm{pH} 7 \cdot 4$; a significant loss occurred overnight at $0^{\circ}$, and no activity was detectable after 4-5 days.

Destruction of factor $I$ activity during repeated ultracentrifugation of washed deposit. In the preparation of the purified deposit $(1.0 \mathrm{ml}$., factor $I$; null point 1/512-1/256) from washed deposit $1.5 \mathrm{ml}$. factor I null point 1/1024) $70-80 \%$ of the factor I activity was lost in the five $6 \mathrm{hr}$. ultracentrifugations (Smith et al. 1956). This loss was due to destruction of activity and not to removal of active material in the five supernatant fluids. Thus, washed deposit (1.5 ml.) was diluted with phosphate buffer $(0 \cdot 2 \mu ; \mathrm{pH} 7 \cdot 4)$ to $13-14 \mathrm{ml}$. (sufficient for one ultracentrifuge tube). A sample was taken for assay and the 
material ultracentrifuged 5 times for $6 \mathrm{hr}$. After each sedimentation, the supernatant fluid was not removed and the deposit was redissolved in it. At the end of the series of ultracentrifugations, the sample had a factor I null point of $1 / 64$ as compared with $1 / 256$ for the original sample tested at the same time.

Effect of oxidizing and reducing agents on factor I activity. A solution of purified deposit (factor I; null point 1/256) in phosphate buffer $(0 \cdot 2 \mu$; pH 7.4) had the factor I null points given in brackets when it was treated with an equal volume of the following reagents (dissolved in $0.2 \mu$ phosphate buffer at $\mathrm{pH} 7 \cdot 4)$ for $16 \mathrm{hr}$. at $0^{\circ}$ : control $(1 / 128) ; 0.2 \%(\mathrm{w} / \mathrm{v})$ cysteine (1/32); $0.1 \%(\mathrm{w} / \mathrm{v})$ sodium metabisulphite $(1 / 8) ; 0.1 \%(\mathrm{w} / \mathrm{v})$ sodium dithionate $(1 / 8)$; 10 vol. hydrogen peroxide $(1 / 128) ; 0.05 \%(\mathrm{w} / \mathrm{v})$ potassium periodate $(1 / 8)$; $0.3 \%(w / v)$ potassium ferricyanide $(1 / 128)$; buffer saturated with $\mathrm{O}_{2}(1 / 256)$ and $0.1 \%(w / v)$ potassium iodate $(1 / 256)$. Thus factor I activity was destroyed by reducing agents but mild oxidizing agents seemed to have a stabilizing effect which was significant though not pronounced. When potassium iodate $(0.1 \% \mathrm{w} / \mathrm{v})$ was added to the purified deposit in $0.2 \mu$ phosphate buffer $(\mathrm{pH} 7 \cdot 4$ ) half to one quarter of the factor I activity remained after 4-5 days at $0^{\circ}$, whereas in the absence of iodate, practically no activity survived this period.

Surface denaturation of factor $I$. A solution (1 ml.) of the purified deposit (factor $I$; null point $1 / 128)$ was shaken vigorously at $0^{\circ}$ in a bottle $(6 \mathrm{ml}$. capacity) containing a few glass beads. After 1, 2, 3, and $4 \mathrm{hr}$. of shaking, the factor $I$ null points were $1 / 16,1 / 16,1 / 8$ and $1 / 8$, respectively. This destruction of factor $I$ activity was accompanied by the formation of a precipitate and was not prevented by the addition of cysteine $(0 \cdot 1 \%, w / v)$ or by replacing the air in the bottle by nitrogen.

Stability of solutions of crude and purified factor I on freeze-drying and at $-20^{\circ}$. Factor I activity of washed deposit was not significantly changed after freezedrying and reconstitution. On the other hand, some batches of purified deposit showed a gross loss of activity and the formation of insoluble material when freeze-dried and reconstituted. Solutions of the crude or the purified deposits were stable for several weeks when frozen and kept at $-20^{\circ}$.

\section{Purification of factor $I$}

In the following fractionations some precautions derived from stability studies were taken in order to preserve the activity of factor I as far as possible: (i) fractionation was carried out at $0-2^{\circ}$ or below, as quickly as possible after collecting the toxic plasma; (ii) samples were not freeze-dried but kept at $-20^{\circ}$ between steps in the fractionation procedure; (iii) in all manipulations foaming was kept to a minimum; (iv) the solvent was $0.2 \mu$ phosphate buffer (pH $7 \cdot 4$ ) containing $0 \cdot 1 \% \mathrm{KIO}_{3}$ ).

Initial separation of factor I from factor II. Toxic plasma (15 ml.) kept at $-20^{\circ}$ was thawed and some inactive insoluble material removed by centrifugation $\left(12,000 \mathrm{~g} ; 20 \mathrm{~min}\right.$; at $\left.0^{\circ}\right)$. The supernatant fluid (13-14 ml.; sufficient to fill a tube of the rotor) was ultracentrifuged for $16 \mathrm{hr}$. in a tube 
marked at $3 \mathrm{ml}$. The first portion of supernatant fluid was removed carefully down to the $3 \mathrm{ml}$. mark. Ice-cold $0 \cdot 2 \mu$ phosphate buffer ( $\mathrm{pH} \gamma \cdot 4$ ) containing $0.1 \%(w / v)$ potassium iodate was added to fill the tube which was then inverted several times, but not shaken vigorously, to dissolve the deposit. The material was then ultracentrifuged for $16 \mathrm{hr}$. and the second supernatant fluid was removed down to the $3 \mathrm{ml}$. mark as described before. The deposit and the remaining supernatant liquid were mixed by gentle stirring with the same buffer as used previously; when the deposit had dissolved, sufficient buffer was added to fill the tube. The mixture was ultracentrifuged for $6 \mathrm{hr}$. and the third supernatant fluid removed down to the $3 \mathrm{ml}$. mark. The deposit was stirred gently to dissolve it in the remaining supernatant fluid; this solution was taken as crude factor $I(N \equiv 4-6 \%$ protein; factor $I$ null point 1/512) and it was sterilized by passing through Millipore filters and frozen at $-20^{\circ}$ until required. The first supernatant fluid described above was ultracentrifuged for $12 \mathrm{hr}$. at $0^{\circ}$ in tubes marked at $1 \mathrm{ml}$. The supernatant fluid was removed carefully down to the $1 \mathrm{ml}$. mark and constituted crude factor II. This was the material used in the assay of factor I (see above) and for further fractionation of factor II.

Precipitation of factor I by $\mathbf{2 5} \%(w / v)$ ammonium sulphate at $-\mathbf{8}^{\circ}$. Crude factor I (10 ml. c. $5 \%$, w/v, protein) was thawed and immediately mixed at $-8^{\circ}$ with an equal volume of $50 \%(\mathrm{w} / \mathrm{v})$ ammonium sulphate dissolved in phosphate buffer $(0 \cdot 2 \mu)$, containing $\mathrm{KIO}_{3}(0 \cdot 1 \%, \mathrm{w} / \mathrm{v})$ and adjusted to $\mathrm{pH} \boldsymbol{\gamma} \cdot 4$. The mixture was kept at $-8^{\circ}$ overnight and the precipitate removed by centrifuging at $12,000 \mathrm{~g}$ for $15 \mathrm{~min}$. at $-8^{\circ}$ and dissolved in phosphate buffer (10 ml., 0.2 $\mu$; $\mathrm{pH} \mathrm{7.4)} \mathrm{containing} \mathrm{KIO}_{3}(0 \cdot 1 \%$, w/v). The precipitation with ammonium sulphate was repeated three times but the mixture was kept only for $1 \mathrm{hr}$. before centrifugation. The final precipitate was dissolved in $10 \mathrm{ml}$. phosphate buffer described above and frozen at $-20^{\circ}$. When 8 batches $(10 \mathrm{ml}$.) of crude factor I having null points of $1 / 512,1 / 512,1 / 512,1 / 512,1 / 512$, $1 / 512,1 / 1024$, were precipitated four times with ammonium sulphate as described above, the final solutions ( $10 \mathrm{ml}$; c. $2 \%, \mathrm{w} / \mathrm{v}$, protein) of the precipitate had factor I null points of $1 / 512,1 / 512,1 / 256,1 / 256,1 / 512,1 / 256$, $1 / 512$, and 1/512, respectively. The four supernatant fluids had negligible factor I activity.

At this stage of purification the factor I activity was extremely labile; attempts to recover active material by direct sedimentation in the ultracentrifuge (3 times for $6 \mathrm{hr}$.) resulted in a loss of over $80 \%$ of the activity. The loss of activity was probably due to excessive concentration of factor $I$ in the sedimented pellet. Experiments (Table 1) indicate that at this stage in the purification factor I was more stable in dilute solution than when concentrated.

Fractionation on diethylaminoethyl cellulose columns at $0-3^{\circ}$. Diethylaminoethyl cellulose ( $2 \mathrm{~g}$.) was equilibrated with $0 \cdot 1 \mu$ phosphate buffer $(\mathrm{pH} 7 \cdot 4)$ and packed as a column $(6 \mathrm{~cm}$. long, $2 \mathrm{~cm}$. diam.). The ammonium sulphate precipitate from $10 \mathrm{ml}$. crude factor I was packed hard in a centrifuge tube by centrifugation as described above. After removing the supernatant fluid, the walls of the tube and the surface of the deposit were washed quickly with ice 
cold $0.005 \mu$ phosphate buffer (pH 7.4) and the precipitate was dissolved in this buffer $(10 \mathrm{ml}$.). When most of the ammonium sulphate was not removed in this way, the excessive ionic strength of the mixture prevented the subsequent adsorption of active material on the column. The solution of the precipitate was sampled for assay, diluted with $0.005 \mu$ phosphate buffer (90 ml.; pH 7.4) and applied to the column. A sufficient positive pressure (c. $3 \mathrm{lb} . /$ sq.in.) was used to ensure that c. $10 \mathrm{ml}$. was collected from the column in $3 \mathrm{~min}$. The column was eluted with $0.2 \mu$ phosphate buffer ( $30 \mathrm{ml}$.; $\mathrm{pH} \mathrm{7 \cdot 4}$ ), $0.2 \mu$ phosphate buffer containing $0.05 \mathrm{M}-\mathrm{NaCl}(30 \mathrm{ml}$.; $\mathrm{pH} 7 \cdot 4)$, and $0.2 \mu$ phosphate buffer containing $0.2 \mathrm{M}-\mathrm{NaCl}(30 \mathrm{ml}$.; $\mathrm{pH} \mathrm{7 \cdot 2)}$. The results of a

Table 1. The increased stability of factor I activity when the $25 \%(w / v)$ ammonium sulphate precipitate was kept at $0^{\circ}$ in dilute solution

These are the results of one experiment representative of four similar experiments on different batches of material.

Conditions of keeping*

(a) At $0^{\circ}$ at the concentration described in the text (approx. $2 \%$ protein)

(b) At $0^{\circ}$ at a 1 in 32 dilution of $(a)$

(c) At $-20^{\circ}$ at the same concentration as $(a)$

* Solvent $0 \cdot 2 \mu$ phosphate buffer containing $0 \cdot 1 \%(w / v) \mathrm{KIO}_{3}$.
After

\begin{tabular}{|c|c|}
\hline $\begin{array}{l}3 \text { days } \\
\text { Factor I nul }\end{array}$ & $\begin{array}{l}9 \text { days } \\
\text { inally } 1 / 512)\end{array}$ \\
\hline $1 / 256$ & $1 / 4$ \\
\hline $1 / 512$ & $1 / 512$ \\
\hline $1 / 512$ & 1/512 \\
\hline
\end{tabular}

typical fractionation are shown in Table 2. In five experiments the total recovery of factor $I$ activity was $70,109,103,80$ and $53 \%$, in all fractions off the column, and $53,100,50,50,46 \%$, respectively, in the active fractions (Fraction 9 and Table 2); the active fractions contained $7 \cdot 1,9 \cdot 0,7 \cdot 8,5 \cdot 1$ and $6.2 \%$, respectively, of the original material which absorbed light at $280 \mathrm{~m} \mu$. The material from the column was more stable at $0^{\circ}$ than the material at the ammonium sulphate precipitate stage. Thus at a concentration of active material equivalent to that shown in line $(a)$ of Table 1 , several batches of material from the cellulose column did not lose more than $50 \%$ of their activity after standing for 9 days at $0^{\circ}$.

Ultracentrifugation. The dilute solution of the active fraction from the column was concentrated for ultracentrifugal analysis. It $(10 \mathrm{ml}$.) was divided equally between two ultracentrifuge tubes (18-13.5 ml. capacity) which were then filled with distilled water and ultracentrifuged for $6 \mathrm{hr}$. The deposit was dissolved in $0 \cdot 2 \mu$ phosphate buffer ( $4 \mathrm{ml}$.; $\mathrm{pH} \mathrm{7.4}$ ). In 5 experiments 100,45 , 80,90 and $40 \%$ of the original activity was recovered in the deposit, with $45,44,50,36$ and $40 \%$ respectively of the material which absorbed at $280 \mathrm{~m} \mu$. The over-all recovery of activity in this fraction from crude factor $I$ was $c$. $20 \%$. Thus $4 \mathrm{ml}$. of a solution of this deposit containing c. $2 \mathrm{mg}$. dry matter 
(after dialysis and freeze-drying) with a factor I null point value of 1/256 was usually obtained from $10 \mathrm{ml}$. of crude factor I containing c. $500 \mathrm{mg}$. nondialysable constituents of factor I null point value $1 / 512$.

The deposit had a sedimentation diagram shown in Fig. 1a. The relative proportion of the peaks depended on the freshness of the original toxin and could be altered by very mild treatment, even by repeated ultracentrifugation. Hence it was difficult to obtain a sample which was reasonably homogeneous in the ultracentrifuge. But this was effected in the following way, which necessitated a large loss of active material in discarded fractions. The eluate $(10 \mathrm{ml}$.) from the column was collected into one ultracentrifuge tube (13$13.5 \mathrm{ml}$.) and the tube filled with water. After ultracentrifugation for $4 \mathrm{hr}$. the supernatant fluid was removed and the deposit dissolved in $0.2 \mu$ phosphate

Table 2. Fractionation of factor I on diethylamino ethyl cellulose columns at $0-3^{\circ}$

\begin{tabular}{|c|c|c|c|c|c|c|}
\hline \multicolumn{2}{|l|}{ Material } & $\begin{array}{l}\text { (1) } \\
\text { Vol } \\
\text { (ml.) }\end{array}$ & $\begin{array}{c}(2) \\
-\log T^{*} \\
\text { at } 2800 \mathrm{~A} \\
\text { in } 0.5 \mathrm{~cm} . \\
\text { optical } \\
\text { cell }\end{array}$ & $\begin{array}{c}\text { (3) } \\
\text { Factor I } \\
\text { null point } \\
\text { (dilution) }\end{array}$ & (1) $\times(2) \dagger$ & $(1) \times \frac{1}{(8)} \ddagger$ \\
\hline \multicolumn{2}{|c|}{$\begin{array}{l}\text { Original ammonium sulphate } \\
\text { precipitate }\end{array}$} & 10 & 8.7 & $1 / 256$ & $87 \cdot 0$ & 2560 \\
\hline $\begin{array}{c}\text { Eluate } \\
0.005 \mu \text { phosphate } \\
(\text { pH } 7 \cdot 4)\end{array}$ & $\begin{array}{c}\text { Fraction } \\
1\end{array}$ & 100 & 0.310 & $\begin{array}{l}\text { Not } \\
\text { active }\end{array}$ & 81.0 & Nil \\
\hline $\begin{array}{l}0.2 \mu \text { phosphate } \\
(\mathrm{pH} \gamma \cdot 4)\end{array}$ & $\begin{array}{l}2 \\
3 \\
4\end{array}$ & $\begin{array}{l}10 \\
10 \\
10\end{array}$ & $\left.\begin{array}{l}0 \cdot 435 \\
2 \cdot 444 \\
0 \cdot 425\end{array}\right\}$ & $\frac{1}{2}$ & 83.0 & 60 \\
\hline $\begin{array}{l}0.2 \mu \text { phosphate con- } \\
\text { taining } 0.05 \mathrm{M}-\mathrm{NaCl} \\
(\mathrm{pH} \gamma \cdot 4)\end{array}$ & $\begin{array}{l}5 \\
6 \\
7\end{array}$ & $\begin{array}{l}10 \\
10 \\
10\end{array}$ & $\left.\begin{array}{l}0 \cdot 165 \\
0 \cdot 380 \\
0 \cdot 215\end{array}\right\}$ & $\frac{1}{t}$ & $7 \cdot 6$ & 120 \\
\hline $\begin{array}{l}\text { 0.2 } \mu \text { phosphate con- } \\
\text { taining } 0 \cdot 2 \mathrm{M}-\mathrm{NaCl} \\
\text { (pH } 7 \cdot 2 \text { ) }\end{array}$ & $\begin{array}{r}8 \\
9 \\
10\end{array}$ & $\begin{array}{l}10 \\
10 \\
10\end{array}$ & $\begin{array}{l}0 \cdot 118 \\
0 \cdot 780 \\
0 \cdot 148\end{array}$ & $\begin{array}{l}\text { Undiluted } \\
\text { 1/256 } \\
1 / 4\end{array}$ & $\begin{array}{l}1 \cdot 2 \\
7 \cdot 8 \\
1 \cdot 2\end{array}$ & $\begin{array}{r}10 \\
2560 \\
40\end{array}$ \\
\hline
\end{tabular}

* Measured in a Unicam Spectrophotometer. The material was diluted until $-\log T$ could be measured between $0 \cdot 1$ and 0.8 ; the reading then multiplied by the dilution involved.

$\uparrow$ A measure of total protein content.

$\ddagger$ A measure of total factor I content.

buffer (pH 7.4) and ultracentrifuged again for $1 \cdot 25 \mathrm{hr}$. The supernatant fluid was removed from a deposit of aggregated material and transferred to another ultracentrifuge tube and the deposit obtained after ultracentrifuging for another $8 \mathrm{hr}$. was the final preparation of factor I. Table 3 shows the yields and activities of the fractions obtained by this process.

\section{Properties of the final preparation of factor $I$}

Examination of the final preparation was restricted by the small amount of material available (c. $2 \mathrm{mg}$. from 20 to 30 large guinea-pigs), its lability at 
pH values much removed from neutrality and its insolubility at moderately acid $\mathrm{pH}$ values.

Biological properties. In the routine assay for factor I activity, different batches of the final product had similar null points at 0.2-0.4 $\mu \mathrm{g}$. Although $0.5 \mu \mathrm{g}$. material produced oedema when mixed with the standard quantity of factor II, $200 \mu \mathrm{g}$. final product had no action in the skin test when injected alone. When mixed with a purified sample of factor II (see below) the final

\section{Table 3. Differential ultracentrifugation of the eluate from diethylamino ethyl cellulose columns}

\begin{tabular}{|c|c|c|c|c|c|}
\hline$=$ & $\begin{array}{l}\text { (1) } \\
\text { Volume } \\
\text { (ml.) }\end{array}$ & $\begin{array}{c}(2) \\
-\log \mathrm{T}^{*} \\
\text { at } 2800 \mathrm{~A} \\
\text { in } 0.5 \mathrm{~cm} . \\
\text { optical } \\
\text { cell }\end{array}$ & $\begin{array}{l}\quad(3) \\
\text { Factor I; } \\
\text { null point } \\
\text { dilution }\end{array}$ & $(1) \times(2) \dagger$ & (1) $\times \frac{1}{(3)}$ \\
\hline Original eluate & $60 \S$ & 0.90 & $1 / 128$ & 54 & 7680 \\
\hline $\begin{array}{l}\text { Ultracentrifuged } 4 \mathrm{hr} \text {. } \\
\text { Supernatant fluid }\end{array}$ & 78 & $0 \cdot 31$ & $1 / 16$ & $24 \cdot 2$ & 1248 \\
\hline $\begin{array}{l}\text { Deposit, dissolved, } \\
\text { ultracentrifuged, } \\
1 \cdot 25 \text { hr. deposit }\end{array}$ & $1 \cdot 4$ & $9 \cdot 1$ & $1 / 1600$ & $12 \cdot 7$ & 2240 \\
\hline $\begin{array}{l}\text { Supernatant fluid ultra- } \\
\text { centrifuged for } 3 \mathrm{hr} \text {. } \\
\text { Supernatant liquid: } \\
\text { Deposit: }\end{array}$ & $\begin{array}{l}78 \\
1 \cdot 4\end{array}$ & $\begin{array}{l}0 \cdot 09 \\
5 \cdot 6\end{array}$ & $\begin{array}{l}1 / 16 \\
1 / 1600\end{array}$ & $\begin{array}{l}7 \cdot 0 \\
7 \cdot 9\end{array}$ & $\begin{array}{l}1248 \\
2240\end{array}$ \\
\hline
\end{tabular}

preparation (25 $\mu \mathrm{g}$.) of factor I produced in rabbits a large oedematous skin lesion of size 9:38 (Smith et al. 1955), but did not do so when anthrax antiserum $(0.1 \mathrm{ml}$.) was included in the mixture injected. At $\mathrm{pH} \mathbf{7 \cdot 4}$ the final product did not lose more than $50 \%$ of its activity after 9 days at $0^{\circ}$; but it was largely inactivated in 2 days at room temperature or in $2 \mathrm{hr}$. at $37^{\circ}$. At $\mathrm{pH} 8.6$ and 6.0 it lost 50-75\% of its activity after standing for 3-4 days at 0-2 ${ }^{\circ}$. It was almost completely inactivated after standing for $16 \mathrm{hr}$. at $0-2^{\circ}$ and $\mathrm{pH} 7 \cdot 4$ with cysteine $(0 \cdot 1 \%)$, sodium metabisulphite $(0 \cdot 1 \%)$ or potassium periodate $(0.05 \%)$; by freeze-drying; by shaking with beads for $1 \mathrm{hr}$. at $0^{\circ}$ in air or nitrogen. The final preparation was immunogenic;0.002 \% (w/v) protected $50 \%$ of the animals in the standard assay for immunizing activity (see Methods).

Serological precipitation with anthrax antisera. The behaviour of the final preparation against various horse antisera is described in a subsequent paper (Sargeant et al. 1960). Although only one serological precipitation line appeared to be formed by the final preparation in the conventional diffusion method, closer examination showed that it contained two or more serological entities, one of which was associated with non-toxic but antigenic factor II. Two guinea-pigs received subcutaneously $30 \mu \mathrm{g}$. final product at 1 week 
intervals for 3 weeks. One week after the final injection the sera of these guinea-pigs formed one line in diffusion plates with the final product.

Two rabbits received subcutaneously six injections $(5 \mu \mathrm{g}$.) of final product at 2-day intervals. After 1 month they received three subcutaneous injections of final product (600 $\mu \mathrm{g}$.) at 2-day intervals. After 2 weeks from final injections, the sera of these rabbits showed diffusion plates with the final product, one strong line and a weak hazy line. The weak hazy line appeared only after standing for several days. The strong line disappeared completely when the sample of factor I was mixed with horse anthrax antiserum before placing it in the well.

Chemical properties. The final preparation of factor I formed a pale yellow brown solution $(0.5 \%, w / v)$ in $0 \cdot 2 \mu$ phosphate buffer (pH 7.4), but was precipitated at $\mathrm{pH} 5 \cdot 6$. After dialysis and freeze-drying it was no longer completely soluble in this buffer. The material migrated rapidly in the ultracentrifuge at $\mathrm{pH} 7 \cdot 4$ in $\mathbf{0 \cdot 2} \mu$ phosphate buffer (Plate $1, b$ ). It still contained some high molecular material, the proportions of which could be increased at the expense of the main peak by mild treatment, e.g. heating to $37^{\circ}$.

The material $\left(0.5 \mathrm{mg}\right.$.) was electrophoresed at $0^{\circ}$ for $16 \mathrm{hr}$. on paper in $0 \cdot 2 \mu$ barbitone buffer ( $\mathrm{pH} \mathrm{8 \cdot 6)}$ ) and $0.05 \mu$ phosphate buffer (pH 7.4) under a potential gradient of $10 \mathrm{v} . / \mathrm{cm}$. at $0-2^{\circ}$. When the paper was stained for protein, one almost stationary band was apparent; there was a tendency for the band to streak towards the anode, but even after electrophoresis for $48 \mathrm{hr}$. there was no separation into two bands.

The final preparation had the following values: $N$ 11.4\%; ash (sulphated) 6.2 \%; carbohydrate (calc. as glucose) $4.5 \%$; P 0.2\%. Paper chromatograms of the material from hydrolysis for $6 \mathrm{hr}$. with $6 \mathrm{~N}-\mathrm{HCl}$ showed the common amino acids. Lipid was estimated as follows: after hydrolysis of the final product (c. $20 \mathrm{mg}$.) with $\mathrm{N}-\mathrm{HCl}$ for $1 \mathrm{hr}$. at $100^{\circ}$ and evaporation to dryness over $\mathrm{P}_{2} \mathrm{O}_{5}$ and $\mathrm{NaOH}, 6.3 \%$ of it was soluble in ether; when the residue was extracted by the method of Folch, Lees \& Sloane-Stanley (1954) the chloroform contained $7 \cdot 4 \%$ of the original material.

\section{Evidence for the presence in the final preparations of factor I of a small amount of constituents of guinea-pig plasma}

Fractionation of normal guinea-pig plasma. Four samples of guinea-pig plasma (containing haemoglobin equiv. c. $10 \%$ of red cells in blood) were fractionated as described for the toxic plasma. All four samples acted similarly during fractionation and the final ultracentrifugation produced deposits, the quantities of which were $12-15 \%$ of those obtained from toxic plasma.

Serological precipitation with rabbit antisera to normal guinea-pig plasma. The final toxic product formed a hazy line after diffusing for some time in serological gel-diffusion plates against a rabbit antiserum prepared against normal heparinized guinea-pig plasma (see Methods). The precipitation line corresponded to the faint line formed beside the main anthrax line, by the final anthrax product with its homologous rabbit antiserum. The small amount of final product, obtained from normal plasma as described above, 
formed the same line with the rabbit antiserum against normal guinea-pig plasma. When the products from normal guinea-pig plasma and the final preparation of factor I were titrated to null points with the same antiserum, the results indicated that the anthrax product was contaminated with $16 \%$ of constituents of guinea-pig plasma.

\section{The stability of factor II in crude preparations}

Effect of freeze-drying. The factor II activity of the crude product was only slightly affected by freeze-drying, by keeping for periods of several weeks and by reconstitution. The null points of most batches remained the same after this treatment; some were $50 \%$ less.

Effect of temperature. A solution of crude factor II in $\mathbf{0 . 2} \mu$ phosphate buffer (pH 7.4; null point 1/32) lost all its activity after incubation at $37^{\circ}$ for $30 \mathrm{~min}$; lost $50 \%$ of its activity after standing at $0-2^{\circ}$ for 1 week, lost all its activity after standing at $0-2^{\circ}$ for 2 weeks; it retained all of its activity when kept at $-20^{\circ}$ for 8 weeks.

Effect of different $\mathrm{pH}$ values at 0-2 ${ }^{\circ}$. In the range $\mathrm{pH} 6 \cdot 5-8.5$ not more than $50 \%$ of the activity was lost in 1 week at $0-2^{\circ}$; outside this $\mathrm{pH}$ range the loss of activity was rapid.

Effect of oxidizing and reducing agents. The addition of $0.02 \mathrm{M}-$ potassium persulphate, potassium ferricyanide, phenol, sodium thioglycollate, cysteine or sodium metabisulphite (final concentration) to a solution of a crude factor II in $0.2 \mu$ phosphate buffer ( $\mathrm{pH} 7 \cdot 4$ ) destroyed half the factor II activity in $24 \mathrm{hr}$. at $0^{\circ}$, and all of it in 5 days at $0^{\circ}$.

Effect of dialysis. On dialysis, all the factor II activity remained in the dialysate residue; none diffused.

\section{Purification of factor II}

Because of the above results, all fractionations were conducted at $\mathbf{0 . 2} \mathbf{2}^{\circ}$, samples were kept at $-20^{\circ}$ between steps in fractionation and as far as possible all work was carried out in the $\mathrm{pH}$ range $6 \cdot 5-8 \cdot 5$.

Fractionation on diethylaminoethyl cellulose columns. In the following procedure crude factor II was placed on the diethylaminoethyl cellulose column and quickly eluted with the same buffer. In this way a fractionation was achieved without appreciable loss of activity. A more conventional procedure, i.e. absorption followed by stepwise elution with buffers of increasing ionic strength, resulted in a gross loss of activity.

Freshly prepared crude factor II was dialysed for 2 days against phosphate buffer $\left(\mathrm{Na}_{2} \mathrm{HPO}_{4} 4 \cdot 26 ; \mathrm{KH}_{2} \mathrm{PO}_{4} 2.72 \mathrm{NaCl} 2 \cdot 77 ; \mathrm{g} / \mathrm{l}\right.$. at pH 6.9). The dialysate (30 ml.; $600 \mathrm{mg}$. protein; factor II null point $\equiv c .64 \mu \mathrm{g}$. protein) was centrifuged $(10,000 \mathrm{~g}$ for $20 \mathrm{~min}$.) to remove inactive insoluble material, and the supernatant fluid applied to a column of diethylaminoethylcellulose (10 g.; $4.5 \mathrm{~cm}$. diam.; $6 \mathrm{~cm}$. long) equilibrated against a second phosphate buffer $\left(\mathrm{Na}_{2} \mathrm{HPO}_{4} 4 \cdot 26 ; \mathrm{KH}_{2} \mathrm{PO}_{4} 2.72 ; \mathrm{g}\right.$./l. $)$. The column was washed at once with the first buffer, with sufficient positive pressure (c. $6 \mathrm{lb}$./sq.in.) to collect c. $10 \mathrm{ml}$. 
from the column every $3 \mathrm{~min}$. The eluate was collected as two fractions: the first (55-75 ml.) contained haemoglobin; the second fraction (150 ml.) was colourless. The factor II activity was equally divided between these fractions. Thus in 20 similar experiments an average of $40 \%$ of the initial activity was in the first fraction and $40 \%$ was present in the second. Since the second fraction contained only about $10 \%$ of the original protein a considerable fractionation of factor II had taken place. The coloured fraction contained about $80 \%$ of the original protein and the remainder adhered strongly in a brown band near the top of the column.

The colourless fraction containing c. $60 \mathrm{mg}$. protein was dialysed (24 hr.) against water and freeze-dried without loss of activity. The factor II activity of the freeze-dried material (null points $\equiv 16 \mu \mathrm{g}$. protein) was unimpaired by storage for several months at $-20^{\circ}$. In the analytical ultracentrifuge the product sedimented as a single component, but in the Tiselius electrophoresis apparatus it showed two components, both moving towards the cathode with mobilities corresponding approximately to albumin and $\alpha$-globulin. After paper electrophoresis for $16 \mathrm{hr}$. in $0.2 \mu$ barbitone buffer $(\mathrm{pH}=8 \cdot 6)$ these two electrophoretic components were resolved; when they were eluted separately, activity was only found to be associated with the minor globulin component.

Separation of the binary mixture by paper electrophoresis. The material from the diethylaminoethyl cellulose column (120 mg.; containing besides salts, c. $60 \mathrm{mg}$. protein) was dissolved in $0.2 \mu$ barbitone buffer $(\mathrm{pH}=8.6 ; 0.7 \mathrm{ml}$. $)$ and applied to 18 Whatman no. 3 papers $(30 \times 4 \mathrm{~cm}$.) in two cooled electrophoresis apparatuses (potential gradient $=10 \mathrm{~V} . / \mathrm{cm}$.). After $16 \mathrm{hr}$. a paper from each apparatus was developed with naphthalene black stain. The major band had moved about $12 \mathrm{~cm}$. and the minor band $7 \mathrm{~cm}$. towards the anode. The remaining 16 papers were cut so as to isolate the minor component which was eluted with phosphate buffer $(0.025 \mathrm{M} ; 3 \times 6 \mathrm{ml}$.). This solution of the final product contained $c .6 \mathrm{mg}$. protein and had a factor II null point equivalent to $4 \mu \mathrm{g}$. protein. Hence electrophoresis had yielded a product containing c. $50 \%$ of the original activity and c. $10 \%$ of the original protein; the use of the ion-exchange column and electrophoresis yielded c. $20 \%$ of the original activity in a product which contained $c .1 \%$ of the original protein. To examine this product, the eluate was concentrated and for chemical analysis freed from salts by dialysis. This entailed a destruction of some factor II activity. After dialysis over-night, at $0^{\circ}$ against water, freeze-drying and reconsitution, $c$. $50 \%$ of the activity was lost; when the product was re-dialysed for 7 days to remove all salt more than $90 \%$ of the activity was lost.

\section{Properties of final preparation of factor II}

Biological properties. The freeze-dried product obtained after dialysis of the final solution for $24 \mathrm{hr}$. was used for these tests; it contained some salt but the quantities and concentrations given below relate to the protein content. When mixed with factor I in the standard assay for factor II activity, $15 \mu \mathrm{g}$. material produced oedema, although $200 \mu \mathrm{g}$. when injected alone was 
innocuous. When $200 \mu \mathrm{g}$. were mixed with the final preparation of factor I described before, it produced a large oedematous skin lesion in rabbits (size 9:38; see Smith et al. 1955), but not when anthrax antiserum was included in the injection mixtures. The final preparation of factor II immunized animals against anthrax but was less active than the final preparation of factor $I$. Thus, $\mathbf{0 . 0 5} \%$ protected $50 \%$ of the animals in the assay for immunizing activity.

Serological precipitation in gels with anthrax antisera. This is described in the following paper (Sargeant et al. 1960). More than one serological component was demonstrable when the final preparation was examined at relatively high concentrations.

Chemical properties. The salt-free freeze-dried product obtained after dialysis of the final solution for 7 days had $\mathrm{N} 13.9 \%$; ash (sulphated) $1.6 \%$; carbohydrate $3.7 \%$ (calculated as glucose); $\mathbf{P} 0.2 \%$. The final product formed one peak in the ultracentrifuge at $\mathrm{pH} 7 \cdot 7$. It (1 mg.) also formed only one band, when examined by paper electrophoresis under three conditions: for $16 \mathrm{hr}$. at $2^{\circ}$ in $0.2 \mu$ barbitone buffer ( $\mathrm{pH} \mathrm{8.6)}$ with a potential gradient of $10 \mathrm{~V} . / \mathrm{cm}$.; for $19 \mathrm{hr}$. at $2^{\circ}$ in $0.05 \mu$ phosphate buffer ( $\mathrm{pH} \mathrm{8)}$ with a potential gradient $7 \cdot 5 \mathrm{~V} . / \mathrm{cm}$.; for $19 \mathrm{hr}$. at $2^{\circ}$ in $0.05 \mu$ acetate buffer (pH 4) with a potential gradient $7 \cdot 5 \mathrm{~V} . / \mathrm{cm}$.

\section{Evidence of gross contamination of the final preparation of factor II}

Although electrophoretic and ultracentrifugal examination showed no evidence of heterogeneity the following evidence indicated that the final preparation of factor II was grossly contaminated with guinea-pig $\alpha$-globulins.

Fractionation of normal guinea-pig plasma. When normal guinea-pig plasma was fractionated in the same way as toxic plasma, the product corresponding to the final preparation of factor II had no factor II activity and gave no serological precipitation lines with anthrax antisera, but the amount of product obtained was about the same as for toxic plasma. The chemical analysis of this product was similar ( $N=13 \cdot 4 \%$; carbohydrate $=5 \cdot 1 \%$ (calculated as glucose); $\boldsymbol{P}<0.1 \%$ to that of the preparation of factor II.

Serological precipitation in gel diffusion plates of the final preparation from toxic plasma by rabbit antisera prepared against the corresponding product from normal plasma. Antisera were prepared in rabbits against the final preparation from normal guinea-pig plasma as follows. Each rabbit received subcutaneously $0 \cdot 03,0 \cdot 06,0 \cdot 13,0 \cdot 25,0.5,1 \cdot 0,1.0$ and $1.0 \mathrm{mg}$. on the 1st, 3rd, 5th, 8th, 10th, 12th, 36th, 38th, 40th days, respectively. The animals were bled and sera prepared on the 53rd day. On serological gel diffusion plates, the final preparation from toxic plasma formed strong precipitation lines with the antiserum against the final preparation from normal plasma. These lines corresponded to those formed by the final product from normal plasma with the same antiserum. 


\section{DISCUSSION}

Although the final preparations contained constituents of guinea-pig plasma, fractionation of factors I and II from toxin produced in vivo was stopped at this stage because of the small amount of material available for further purification and for the following reason. Anthrax toxin was produced in vitro by Harris-Smith, Smith \& Keppie (1958) who used a serum medium, and our colleagues C. B. Thorne and R. E. Strange (private communication) have produced anthrax toxin in a simple medium in vitro. This offered the possibility of fractionating the two factors from a non-protein medium, and hence obtaining purer products than those separated from guinea-pig plasma.

The information given here about the lability and fractionation of in vivo product facilitated the fractionation of factor I from in vitro cultures. The properties of this final product will be described later.

With regard to the isolation of factor II from in vitro sources, impure preparations of a protective antigen (Strange \& Belton, 1954) were shown to have factor II activity by Smith et al. (1956). Recently Strange \& Thorne (1958) obtained a more purified product which was apparently serologically homogeneous. This preparation was shown by us to have factor II activity, but proved to be serologically inhomogeneous when compared with the preparations of factors I and II obtained as described here from toxin produced in vivo, and with the preparation of factor I from culture in vitro (see next paper).

Our thanks are due to our colleagues at M.R.E. especially Dr J. Keppie for help in collecting the toxic plasma. We are indebted to Mr R. Hale and Mr A. Annetts for technical assistance.

\section{REFERENCES}

Folch, J., Lees, M. \& Sloane-Stanley, G. H. (1954). A simple method for preparation of total pure lipide extracts from brain. Fed. Proc. 13, 209.

Harris-Smith, P. W., Smith, H. \& Keppie, J. (1958). Production in vitro of the toxin of Bacillus anthracis previously recognized in vivo. J. gen. Microbiol. 19, 91.

Peterson, E. A. \& Sober, H. A. (1956). Chromatography of proteins. I. Cellulose ion-exchange adsorbents. J. Amer. chem. Soc. 78, 751 .

Sargeant, K. \& Smith, H. (1958). Purification of factor II of the anthrax toxin produced in vivo using cellulose ion-exchange columns. Biochem. J. 69, $55 \mathrm{P}$.

Sargeant, K., Stanley, J. L. \& Smith, H. (1960). Serological relationship between purified preparations of factors I and II of the anthrax toxin produced in vivo and in vitro. J. gen. Microbiol. 22, 219.

Smith, H. \& Gallop, R. C. (1956). The chemical basis of the virulence of Bacillus anthracis. VI. An extracellular immunising aggressin isolated from exudates of infected guinea pigs. Brit. J. exp. Path. 37, 144.

Smith, H., Keppie, J. \& Stanley, J. L. (1955). The chemical basis of the virulence of Bacillus anthracis. V. The specific toxin produced by $B$. anthracis in vivo. Brit. J. exp. Path. 36, 460.

Smith, H., Tempest, D. W., Stanley, J. L., Harkis-Smith, P. W. \& Gallop, R.C. (1956). The chemical basis of the virulence of Bacillus anthracis. VII. Two components of the anthrax toxin: their relationship to known immunizing aggressins. Brit. J. exp. Path. 37, 263. 
Sørensen, M. \& HaUgaARd, G. (1983). Utber die Anwendbarkeit der Orcinreaktion zur bestimmung der Art und Merge von Kohlen-hydratgruppen in EiweissStoffen. Biochem. Z. 260, 247.

Stanley, J. L. \& Smrth, H. (1958). Purification of factor I of the anthrax toxin produced in vivo. Biochem. J. 69, $55 \mathrm{P}$.

Strange, R. E. \& Belton, F. C. (1954). Studies on a protective antigen produced in vitro from Bacillus anthracis: purification and chemistry of the antigen. Brit. J. exp. Path. 35, 153.

Strange, R. E. \& Thorne, C. B. (1958). Further purification studies on the protective antigen of Bacillus anthracis produced in vitro. J. Bact. 76, 192.

\section{EXPLANATION OF PLATE}

Spinco ultracentrifuge diagrams obtained during the purification of factor $I$ of anthrax toxin. Fractions were dissolved in $0.2 \mu$ phosphate buffer $(\mathrm{pH} 7 \cdot 4)$ and examined in a field of $240,000 \mathrm{~g}$. Photographs were taken $16 \mathrm{~min}$. after reaching full speed with bar angle $=45^{\circ}$ and were aligned according to the meniscus of the liquid in the optical cell. (a) Preparation ( $0.4 \%$ ) obtained by ultracentrifuging the active fraction from the ion exchange column for $6 \mathrm{hr}$. (b) Final product $(0 \cdot 6 \%)$ obtained by differential ultracentrifugation.

(Received 15 July 1959) 
Journal of General Microbiology, Vol. 22, No. 1

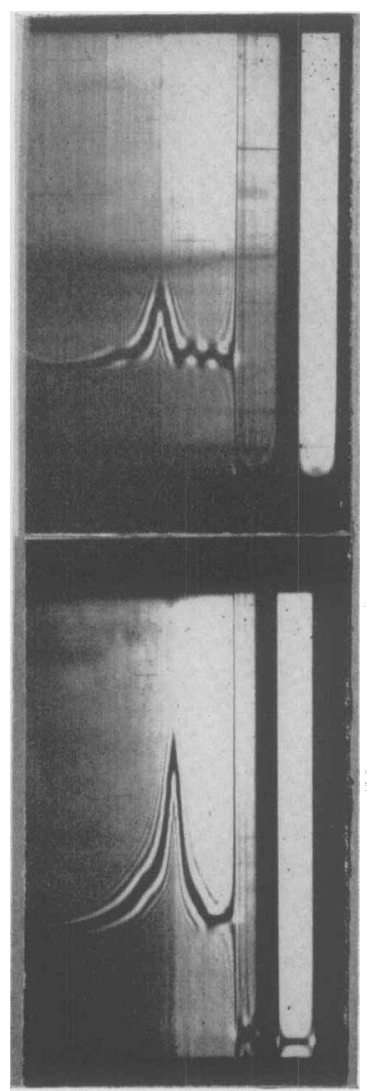

(a)

(b)

J. L. Stanley, K. Sakgeant \& H. Smith--Factors I and II of an'Thkax toxin

(Facing p. 218) 